\title{
Blockade of the checkpoint as new target of the immunotherapy in the treatment of cancer
}

\section{Kanser tedavisinde immünoterapinin yeni hedefi olarak kontrol noktası blokajı}

\author{
Betül YAŞİN ${ }^{1}$, Nüket ÖZKAVRUK ELIYATKIN ${ }^{2}$ \\ ${ }^{1}$ Adnan Menderes Üniversitesi, Temel Onkoloji ve Kanser Biyolojisi Anabilim Dalı, Aydın, Türkiye \\ ${ }^{2}$ Adnan Menderes Üniversitesi, Patoloji Anabilim Dalı, Aydın, Türkiye
}

\begin{abstract}
In the treatment of cancer, immunotherapy is applied to retrieve more precisely targeted activities from the components of immune systems via development of treatments mimicking immune system. To this end investigators in the field of oncology have conducted many studies concerning immunotherapy. Cancer cells lead a relatively more independent, and uncontrolled life with their ability to evade from immune system when compared with normal cells. Blockade of the checkpoint has opened the way for a new targeted oncological treatment modalities. In this paper we will briefly review potential position of anti-PD-1, and anti-PD-L1 as novel, and very popular treatment approaches in cancer.
\end{abstract}

Key words: PD-L1, PD-1, blockade of checkpoint, cancer, immunotherapy

$\ddot{\mathbf{O} Z}$

Kanser tedavisinde, immünoterapi, bağışıklık sistemini taklit eden tedavilerin geliştirilmesi yoluyla bağışıklık sistemi elemanlarından daha kesin hedefleri olan aktivite elde etmek için uygulanır. Bu nedenle kanser araştırmacıları tarafından son yıllarda, immunoterapi konusunda çok sayıda çalışma yapılmıştır. Kanser hücreleri, immün sistemden kaçabilme yeteneği ile normal hücrelerden daha bağımsız ve kontrolsüz bir yaşam sürer. Kontrol noktası blokajı kanser tedavisinde yeni bir hedefe yönelik tedavinin önünü açmıştır. Bu makalede, kanserde yeni ve çok popüler olan bir yaklaşım modalitesi olarak anti-PD-1 ve anti-PD-L1 gibi ajanların bugünkü ve gelecekteki olası durumlarını kısaca gözden geçireceğiz.

Anahtar kelimeler: PD-L1, PD-1, kontrol noktası blokaji, kanser, immünoterapi

\author{
Alındığı tarih: 20.06.2017 \\ Kabul tarihi: 25.06 .2017 \\ Yazışma adresi: Doç. Dr. Nüket Özkavruk Eliyatkın, \\ Adnan Menderes Üniversitesi, Patoloji Anabilim \\ Dalı, Aydın, Türkiye \\ e-mail: drnuket2003@yahoo.com.tr
}

\section{INTRODUCTION}

In the treatment of cancer, immunotherapy is applied to retrieve more precisely targeted activities from the components of immune systems via development of treatments mimicking immune system. To this end investigators in the field of oncology have conducted many studies concerning immunotherapy. The firstly applied models of immunotherapy may be considered as use of local inflammatory agents as intravesical instillation of BCG in the treatment of bladder cancer, cancer vaccines developed for various types of can- cer, allogenic stem cell transplantation for the treatment of bone marrow cancers, cellular therapies as hematopoietic stem cell therapy, use of proinflammatory cytokines in the treatment of pancreatic adenocarcinomas, and immune-checkpoint inhibitors. Long-term remission may be achieved with successful immunotherapy. However because of its marked toxicity, and decreased effectiveness immunotherapy has a limited indication for use. In order to be able get rid of this marked toxicity in question, recognition, and discovery of the agents which effectively, and specifically activate immune system components, and 
potentially eradicate cancer without activating factors inducing toxicity have gained utmost importance.

Cancer cells lead a relatively more independent, and uncontrolled life with their ability to evade from immune system when compared with normal cells. Cancer cells succeed in escaping from immune system via various, and fairly complex mechanisms including down-regulation of foreign tumor antigens which remain in situ without being noticed, formation of a immunosuppressive microenvironment by secreting anti-inflammatory cytokines, and expression of agents involving in the negative regulation of immune responses which effectively silence immune cells fighting against cancer cells. One of the basic interplays between cancer, and the immune system involve binding signal of PD-L1 (Programmed cell Death Ligand-1) to PD-1 (Programmed cell Death). As a classical information we know that PD-L1 is localized on the surface of tumor cells, while PD-1 is situated on the surface of activated $\mathrm{B}$ and $\mathrm{T}$ cells ${ }^{(1,2)}$ (Figure 1). In various studies expression of PD-L1 by many different tumors has been reported ${ }^{(1-4)}$. Based on this finding, recently, development of agents inhibiting the interaction between PD-1, and PD-L1 has become a promising advancement in the treatment of cancer patients ${ }^{(1-7)}$. These agents have exerted potent effects with minimal toxicity, and prolonged survival.

In this paper we will briefly review potential position of anti-PD-1, and anti-PD-L1 as novel, and very popular treatment approaches in cancer.

\section{Identification and role of PD-1 and its ligands in cancer evasion}

Firstly, in an in vivo immunosuppressive mice model negative regulatory function of PD- 1 has been

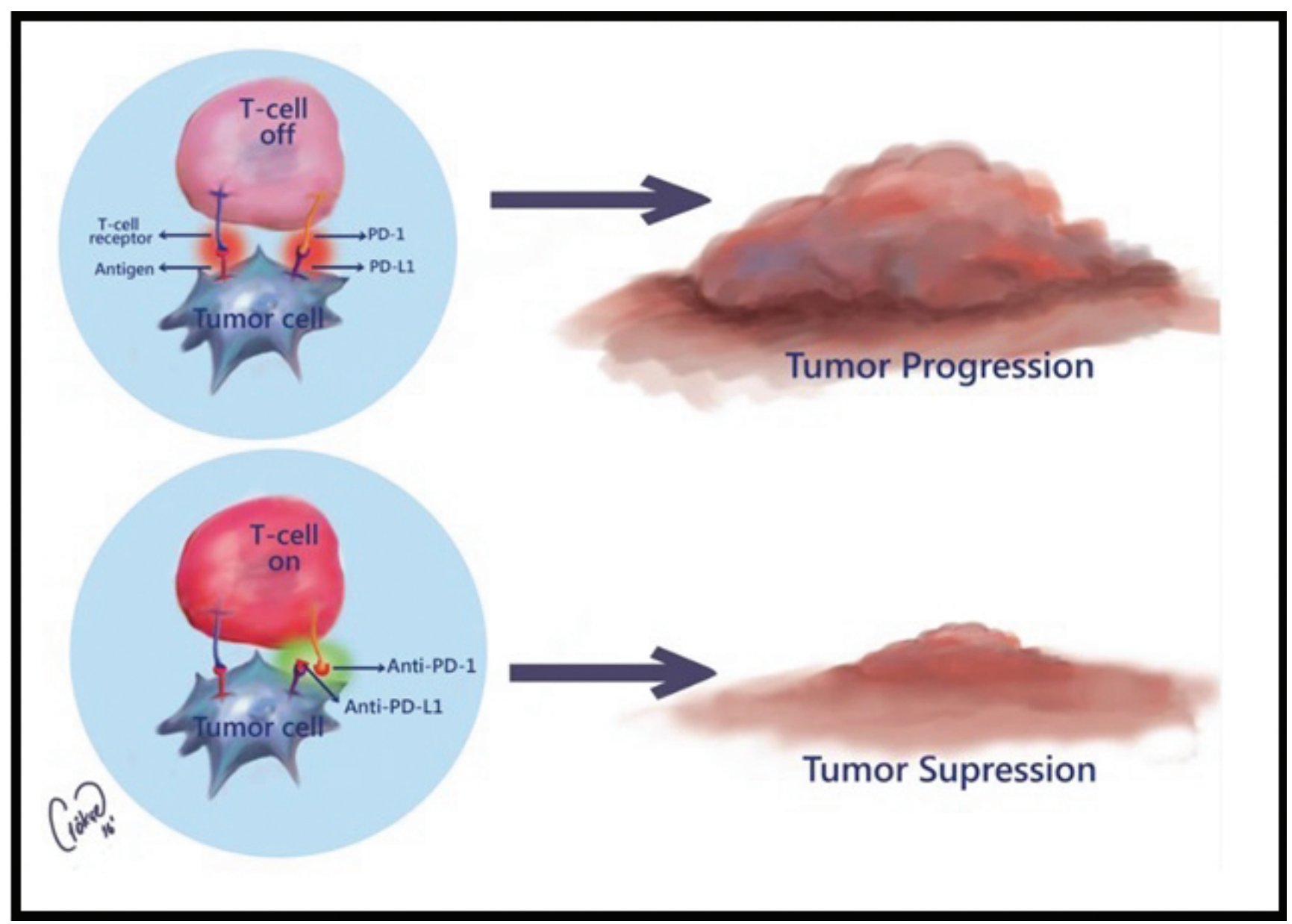

Figure 1. Note that PD-L1 is localized on the surface of tumor cells, while PD-1 is situated on the surface of activated T cells. 
demonstrated ${ }^{(8)}$. Under normal conditions PD-1 is a costimulatory molecule expressed on immune system cells during response to inflammation. PD-L1 is the first ligand defined for PD-1 receptor. Binding of PD-L1 to PD-1 inhibits T-cell receptor- mediated proliferation of lymphocytes, and secretion of cytokines with resultant inhibition of immune response ${ }^{(2)}$. As an important, and normal component of immune regulation mechanism, interaction between PD-L1, and PD-1 plays a role in the prevention from autoimmunity, and response to inflammation. This process is important in the inhibition of host tissue damage in cases of immune system activation. After discovery of PD-L1, the expression of this molecule on the surface of many tumors has been revealed. Probable effect of this expression on tumor immune evasion has been also demonstrated.

The interaction between type 1 transmembrane receptor PD-1 which belongs to the superfamily of immunoglobulins expressed by activated $\mathrm{T}$ cells, and their binding ligands PD-L1/PD-L2 is a normal component of immune regulation. PD-1 is recognized as a necessary molecule which prevents natural tissue damage, and protects autoimmunity because of immune system activation as a response to inflammation ${ }^{(9,10)}$. Some time later investigators have demonstrated that PD-L1 is expressed on the surface of multiple tumors, and induces evasion of the tumor from immune system ${ }^{(1)}$.

Checkpoints other than PD-L1 also play a role in the immune regulation. PD-L2 is a second ligand which enables activation, and proliferation of T-cells, and also it may inhibit production of cytokines ${ }^{(11)}$. PD-L2 has been demonstrated in B-cell lymphomas, and Hodgkin's disease ${ }^{(12)}$. PD-L1 is expressed in multiple normal tissues, and malignant cells while PD-L2 is essentially expressed from antigenpresenting cells ${ }^{(13-15)}$.

Different from traditional cytotoxic chemotherapies or target treatments, evaluation of the effectiveness of immunotherapy poses some difficulties due to different reasons.

In some patients, during transient periods of exa- cerbations, new lesions may become manifest during a process known as pseudoregression ${ }^{(16)}$. Besides assessment of regression of a solid tumor in patients undergoing immunotherapy may be a challenging issue. Therefore as a matter of utmost importance, one should be certain about the beneficial effects of this class of drugs, and the tumor biology which they may confer benefit should be accurately determined. In many studies, it has been proved that patients with PD-L1-positive tumors derive greater amount of benefit from anti-PD-1 and anti-PD-L1 treatments when compared with PD-L1 negative patients ${ }^{(17,18)}$. It has been also indicated that even at a lesser extent, patients with PD-L1 negative tumors may benefit from this treatment ${ }^{(19)}$. However evaluation of PD-L1 has not been standardized yet. Various anti-PD-L1 antibodies have been used in different studies. Another confounding factor is that quantitative analysis of PD-L1 has been performed using various methods. As a challenging issue, these treatments have been more beneficial in cases where expression of PD-L1 is induced by immune infiltration, rather than tumor cells ${ }^{(20)}$. Still a standardized method is not available for the evaluation of PD-L1 expression. Most prevalently immunohistochemical methods have been used. However different outcomes have been obtained by using different antibody clones ${ }^{(21)}$. However when the same antibodies were used different outcomes may be obtained when tissue specimens fixated in formalin or freshly frozen tissue specimens have been used. Heterogeneity of the tumor is another confounding matter. Two different specimens from the same tumor tissue may yield different results. More importantly expression of PD-L1 is a dynamic process which may vary with time. PD-L1 may be evaluated using RT-PCR apart from immunohistochemical methods. A strong correlation was reported between IHC methods, and RT-PCR technique ${ }^{(22)}$. Further studies are needed to evaluate patients who will benefit optimally, and most accurately from antiPD1 and anti PD-L1 treatments. 


\section{Blockade of PD-1/PD-L1/PD-L2 pathway in cancer}

Blockade of the checkpoint has opened the way for a new targeted treatment modalities. Binding of PD-1 to PD-L1, and PD-L2 inhibits activation of T-cells which enables evasion of cancer cells from immune system ${ }^{(23)}$. The interaction between costimulator molecule PD-1 with its ligand PD-L1 is known to play a role in the regulation of both $\mathrm{T}_{\text {reg }}$ and Th17 cells. This interaction leads to proliferation of $\mathrm{T}_{\text {reg }}$ cells which suppress effector immune responses more strongly. Blockade of PD-1/PD-L1 decreases both effectiveness of $\mathrm{T}_{\text {reg }}$, and the number of Th17 inflammatory cells.

Immunoregulatory function of PD-1 has been demonstrated by the inhibition of effector phase of T-cells in the microenvironment of the tumor. Development of autoimmune disease has been demonstrated in mice where PD-1 gene expression was silenced ${ }^{(1,24)}$. When mechanism used by cancer cells for evasion from immune system is considered, inhibition of PD-1/PD-L1 interaction pathway has been predicted to demonstrate higher antitumoral activity with fewer side effects when compared with blockade of CTLA4 (Cytotoxic T-Lymphocyte Associated Protein 4) ${ }^{(25,26)}$. Within this context, increased number of studies have been performed on antibodies blocking PD-L1 ${ }^{(27)}$.

Currently FDA-approved pembrolizumab and nivolumab as anti-PD1 antibodies are being used in the treatment of malignant melanoma. Anti-PD-1 / PD-L1 antibodies continue to be investigated in other malignancies.

\section{CONCLUSION}

Generally immunotherapy functions through a mechanism which prevents evasion of tumor cells from immune system as a result of blockade of cellular checkpoints induced by T-cell activation ${ }^{(28)}$. An anti-CTLA4 antibody, ipilimumab, is the first molecule which blocked these checkpoints via monoclo- nal antibody technology with resultant prolongation of patient's survival. It was firstly used in patients with advanced stage malignant melanoma. Afterwards, blockade of PD-1/PD-L1 pathway has been very effective in patients with advanced stage malignant melanoma ${ }^{(29)}$.

Combination treatment with anti-CTLA4 and anti-PD-1 antibodies is the subject to be investigated for use in the treatment of early stage malignant melanoma patients ${ }^{(27)}$. This class of immune modulator antibodies which block PD-1 or PD-L1 has achieved great success in the drug development for cancer treatment.

Anti PD1 or PDL1 treatments have been used in patients with various malignancies. Apart from FDAapproved PD1 antibodies as pembrolizumab, and nivolumab, new drugs of this class are awaiting for FDA approval. Generally very effective outcomes have been obtained with these agents having lower toxicity levels. In addition to their recognized therapeutical success, increasing their clinical efficacies by discovering their unknown properties has been also suggested. Therefore new data will be obtained with their various combinations. Besides, these new data will enable more comprehensive understanding of this immune response, and also provide information about its clinical usefulness (if any) ${ }^{(19)}$.

\section{REFERENCES}

1. Dong H, Strome SE, Salomao DR, et al. Tumor-associated B7-H1 promotes T-cell apoptosis: a potential mechanism of immune evasion. Nat Med. 2002;8(8):793-800. https://doi.org/10.1038/nm730

2. Freeman GJ, Long AJ, Iwai Y, et al. Engagement of the PD-1 immunoinhibitory receptor by a novel B7 family member leads to negative regulation of lymphocyte activation. J Exp Med. 2000;192(7):1027-34. https://doi.org/10.1084/jem.192.7.1027

3. Thompson RH, Gillett MD, Cheville JC, et al. Costimulatory B7-H1 in renal cell carcinoma patients: Indicator of tumor aggressiveness and potential therapeutic target. Proc Natl Acad Sci U S A. 2004;101(49):17174-9. https://doi.org/10.1073/pnas.0406351101

4. Liu JZ, Hamrouni A, Wolowiec D, et al. Plasma cells from multiple myeloma patients express B7-H1 (PD-L1) and increase expression after stimulation with IFN-gamma and TLR ligands via a MyD88-, TRAF6-, and MEK-dependent pathway. Blood. 2007;110(1):296-304. 
https://doi.org/10.1182/blood-2006-10-051482

5. Chen BJ, Chapuy B, Ouyang J, et al. PD-L1 expression is characteristic of a subset of aggressive B-cell lymphomas and virus-associated malignancies. Clinical Cancer Research. 2013;19(13):3462-73. https://doi.org/10.1158/1078-0432.CCR-13-0855

6. Inman BA, Sebo TJ, Frigola X, et al. PD-L1 (B7-H1) expression by urothelial carcinoma of the bladder and BCG-induced granulomata. Cancer. 2007;109(8):1499-1505. https://doi.org/10.1002/cncr.22588

7. Lyford-Pike S, Peng S, Young GD, et al. Evidence for a role of the PD-1: PD-L1 pathway in immune resistance of HPVassociated head and neck squamous cell carcinoma. Cancer Research. 2013;73(6):1733-41. https://doi.org/10.1158/0008-5472.CAN-12-2384

8. Nishimura $\mathrm{H}$, Nose $\mathrm{M}$, Hiai $\mathrm{H}$, Minato $\mathrm{N}$, Honjo $\mathrm{T}$. Development of lupus-like autoimmune diseases by disruption of the PD-1 gene encoding an ITIM motif-carrying immunoreceptor. Immunity. 1999;11(2):141-51. https://doi.org/10.1016/S1074-7613(00)80089-8

9. Barber DL, Wherry EJ, Masopust D, et al. Restoring function in exhausted CD8 $\mathrm{T}$ cells during chronic viral infection. Nature. 2006;439(7077):682-7. https://doi.org/10.1038/nature04444

10. Ramsay AG. Immune checkpoint blockade immunotherapy to activate anti-tumour T-cell immunity. British Journal of Haematology. 2013;162(3):313-25. https://doi.org/10.1111/bjh.12380

11. Latchman Y, Wood CR, Chernova T, et al. PD-L2 is a second ligand for PD-1 and inhibits $\mathrm{T}$ cell activation. Nature Immunology. 2001;2(3):261-8. https://doi.org/10.1038/85330

12. Steidl C, Shah SP, Woolcock BW, et al. MHC class II transactivator CIITA is a recurrent gene fusion partner in lymphoid cancers. Nature. 2011;471(7338):377-81. https://doi.org/10.1038/nature09754

13. Hammers H, Plimack E, Infante J, et al. Phase I study of nivolumab in combination with ipilimumab (ipi) in metastatic renal cell carcinoma (mrcc). Bju International. 2014; $114: 8$.

14. Sunshine J, Taube JM. Pd-1/Pd-L1 inhibitors. Current Opinion in Pharmacology. 2015;23:32-8. https://doi.org/10.1016/j.coph.2015.05.011

15. Wolchok JD, Kluger H, Callahan MK, et al. Nivolumab plus ipilimumab in advanced melanoma. New Engl J Med. 2013;369(2):122-33. https://doi.org/10.1056/NEJMoa1302369

16. Topalian SL, Hodi FS, Brahmer JR, et al. Safety, activity, and immune correlates of anti-PD-1 antibody in cancer. New Engl J Med. 2012;366(26):2443-54. https://doi.org/10.1056/NEJMoa1200690

17. Daud AI, Hamid O, Ribas A, et al. Abstract CT104: antitumor activity of the anti-PD-1 monoclonal antibody MK-3475 in melanoma (MEL): Correlation of tumor PD-L1 expression with outcome. AACR; 2014.

18. Gandhi L, Balmanoukian A, Hui R, et al. Abstract CT105: MK-3475 (anti-PD-1 monoclonal antibody) for non-small cell lung cancer (NSCLC): Antitumor activity and association with tumor PD-L1 expression. AACR; 2014.

19. Swaika A, Hammond WA, Joseph RW. Current state of antiPD-L1 and anti-PD-1 agents in cancer therapy. Mol Immunol. 2015;67(2 Pt A):4-17. https://doi.org/10.1016/j.molimm.2015.02.009

20. Herbst RS, Soria J-C, Kowanetz M, et al. Predictive correlates of response to the anti-PD-L1 antibody MPDL3280A in cancer patients. Nature. 2014;515(7528):563-7. https://doi.org/10.1038/nature14011

21. Gadiot J, Hooijkaas AI, Kaiser AD, van Tinteren H, van Boven H, Blank C. Overall survival and PD-L1 expression in metastasized malignant melanoma. Cancer. 2011;117(10):2192-2201. https://doi.org/10.1002/cncr.25747

22. Joseph RW, Parasramka M, Eckel-Passow JE, et al. Inverse Association between Programmed Death Ligand 1 and Genes in the VEGF Pathway in Primary Clear Cell Renal Cell Carcinoma. Cancer Immunology Research. 2013;1(6):378-85. https://doi.org/10.1158/2326-6066.CIR-13-0042

23. Pardoll DM. The blockade of immune checkpoints in cancer immunotherapy. Nature Reviews Cancer. 2012;12(4):252-64. https://doi.org/10.1038/nrc3239

24. Jacobs JFM, Idema AJ, Bol KF, et al. Regulatory T cells and the PD-L1/PD-1 pathway mediate immune suppression in malignant human brain tumors. Neuro-Oncology. 2009;11(4):394-402. https://doi.org/10.1215/15228517-2008-104

25. Gettinger SN, Shepherd FA, Antonia SJ, et al. First-line nivolumab (anti-PD-1; BMS-936558, ONO-4538) monotherapy in advanced NSCLC: Safety, efficacy, and correlation of outcomes with PD-L1 status. American Society of Clinical Oncology. 2014.

26. Robert C, Ribas A, Wolchok JD, et al. Anti-programmeddeath-receptor-1 treatment with pembrolizumab in ipilimumab-refractory advanced melanoma: a randomised dose-comparison cohort of a phase 1 trial. The Lancet. 2014;384(9948):1109-17. https://doi.org/10.1016/S0140-6736(14)60958-2

27. Shin DS, Ribas A. The evolution of checkpoint blockade as a cancer therapy: what's here, what's next? Current Opinion in Immunology. 2015;33:23-35. https://doi.org/10.1016/j.coi.2015.01.006

28. Callahan MK, Wolchok JD. At the Bedside: CTLA-4-and PD-1-blocking antibodies in cancer immunotherapy. J Leukocyte Biol. 2013;94(1):41-53.

https://doi.org/10.1189/jlb.1212631

29. Hamid O, Robert C, Daud A, et al. Safety and Tumor Responses with Lambrolizumab (Anti-PD-1) in Melanoma. New Engl J Med. 2013;369(2):134-44. https://doi.org/10.1056/NEJMoa1305133 